\title{
CALCULATION OF MAGNETIC DAMPER
}

TATARCHUK T.V.

HAVROV A.I.

MASLOV S.O.
$\mathrm{PhD}$ Tech., associate professor of Physics Department of National University "Zaporizhzhia Polytechnic", Zaporizhzhia, Ukraine, e-mail: tanko.ho1@gmail.com;

student of the E-127sp group of National University "Zaporizhzhia Polytechnic", Zaporizhzhia, Ukraine, e-mail: lordbusya@gmail.com

student of the E-127sp group of National University "Zaporizhzhia Polytechnic", Zaporizhzhia, Ukraine, e-mail: ser.maslov.97@gmail.com.

Purpose. To investigate the dependence of the magnetic properties of a material on its chemical composition obtained at different pressures at certain temperatures. On the basis of the specific composition and properties of this material, to investigate how its operating points and loss of re-magnetization change, which in turn will affect the structural and operational characteristics of the magnetic damper of engine.

Methodology. Selection of the function extrema of the magnet energy dependence on induction and intensity through differentiation of expression, calculation of operating points of the magnet by the method of selection and using the MathCad medium, determination of the energy of re-magnetization through the integration of hysteresis loops, analytical calculation of magnetic forces in a magnetic damper using Beamer experiment formulas.

Findings..In the course of this task the operating points of the magnet hysteresis loop were determined, in which the magnetic energy is greatest by differentiating the expression of the dependence of the magnet energy on induction and intensity. On the basis of these data, the maximum magnetic induction was found to be the tertiary force of the magnetic field at these points. These points characterize the highest specific energy of the magnet, which is further used as intended. Then, based on the hysteresis loop, the energy of losses on the re-magnetization of the magnet was found by integration. According to these data, the unloading force of the magnetic damper was calculated.

Originality. More accurate analysis of magnetic processes in magnetic materials was conducted using a mathematical apparatus, software environments such as MathCad, OriginLaB. The dependence of the material magnetic properties on its chemical composition, energy and losses is analyzed, which in turn makes the use of a permanent magnet more efficient in engineering, apparatus and machines.

Practical value. According to the obtained results of calculation of energy losses and operating points of the magnet, the optimal chemical composition, its geometric size is determined, which allows to reduce production losses, save materials while increasing the efficiency of magnetic material in engine design. This increases both operational life of the machines and their reliability. The optimum dimensions of the magnets in the windings provide the required air gaps, which in turn, due to the absence of friction, reduce losses increasing the unloading force.

Keywords: Magnet materials; hysteresis loop; operating point; energy loss; magnetic damper; magnetic induction, unloading force, saturation induction, tension, coercive force.

\section{INTRODUCTION}

In the aviation industry, the main goal of turbojet engine developers is to create highly economical and reliable, low-specific power plants. The resource and reliability of modern machines with rotating elements to a large extent depend on the level of vibration, the longevity of the bearings, the magnitude of the dynamic loads caused by the rotor imbalance. One of the reasons that causes an increased level of vibration on the aircraft engine is the increased rotor (or rotors) imbalance, which can lead to the excitation of one or more critical velocities of its own oscillations of the rotor, as well as cause resonance phenomena in the supporting structure [1], [3], [6]. The most effective measures of reducing vibration and dynamic loads at engine nodes is to use damping supports. Rotor supports are separate modules that are part of the engine's power system. The designs of the damping supports are quite diverse, however they have the following basic functions: to reduce the stiffness of the rotor support, which leads to change of the elastic dynamic system of the engine (thus reducing the frequencies of natural oscillations of the system, eliminating resonances in operating modes) and to absorb energy of engine dynamic system oscillations, converting it to heat, which does not allow the development of large amplitudes of oscillations, dynamic loading and stress in the engine parts.

At the Ivchenko-Progress State Enterprise, when the D-436T1 engine was adjusted (carrying out a special check on the fan wheel), at the fan speeds of 5900...6100 $\mathrm{rpm}$, increased vibrations of the engine at rotor frequencies were caused by resonant vibrations of the fan shaft. These oscillations caused the fan shaft to bend and touch the stator and rotor parts of the low pressure compressor. Changing the fan shaft design to eliminate 
the resonance was impossible. The fan wheel extensions and the elasto-oil damper available in the fan design did not provide resonance. In order to solve the aforementioned problem, in cooperation with the Ivchenko-Progress SE, in accordance with the cooperation agreement, the following task was set: to develop a design of such a damper that would allow the existing geometric dimensions not to change the engine assembly technology and ensure the efficiency of the engine in all modes of operation.

To solve this problem it is necessary to use a mathematical apparatus and modeling, with which you can quite accurately investigate the characteristics of the magnetic material. Increasing the coercive force will make it possible to obtain higher operating points at which the specific energy of the magnet is the highest. Larger operating points allow more energy to be generated from permanent magnet operation. Accordingly, if you know the maxima of the working range of these materials, it is possible to achieve a reduction in the dimensions of the magnetic material in the design of equipment or device. This will save on materials and make their production more ergonomically advantageous and cheaper. In turn, reducing the size will lead to the development of industries such as nanotechnology, robotics and microprocessor technology. In addition, the reduction of remagnetization losses can be achieved by calculating the operating points of the magnet, analyzing the residual induction and coercive force. It is also possible to develop methods for extending the life of magnetic materials and storing residual induction without remagnetization.

\section{II.ANALYSIS OF EXPERIMENTS AND PUBLICATIONS}

With the development of aircraft construction, design of turbine engines, etc., the issues of modernization and increase of their reliability were considered. In scientific-educational institutions, design bureaus were engaged to improve aircraft engines, first of all their vibration resistance by various methods including damping. There are publications by such authors as: Ponomarev Yu.K., Pronichev Yu.N., Chehodaev D.E., Kyrylyn A.N., Vershyhorov V.M. Works and books of these authors are devoted to the topic of damping aircraft engines. They illustrated important issues of using multi- and singlelayer dampers, corrugated dampers, investigated hydrodynamic damping, structural features of dampers, etc. And the issue of magnetic properties, chemical composition, received little attention. No correlation was found between the magnetic properties and the composition of the magnet used to make the damping windings. This work, in comparison with others, by mathematical analysis of magnetic properties, energy and losses of magnets helps to achieve optimal geometric dimensions, find a certain chemical composition of the permanent magnet, which will more efficiently perform functions in aircraft engines, compressors, etc. and will be more cost- effective. For conventional electric motors, generators with a damping winding, the issues of better quenching of short-circuit currents and eddy currents will be solved.

\section{FORMULATION OF THE WORK PURPOSE}

Purpose of the study. Calculate the operating points of permanent magnets consisted of $\mathrm{Nd}_{15,2} \mathrm{Fe}_{74,99} \mathrm{~B}_{6,6} \mathrm{C}_{0,51} \mathrm{Cu}_{1,57} \mathrm{Ti}_{1,38}$, obtained under different conditions, by direct point selection and using the MathCad environment, as well as the re-magnetization energy for these samples.

Assignment of the study.

1. To calculate the operating points of permanent magnets consisted of $\mathrm{Nd}_{15,2} \mathrm{Fe}_{74,99} \mathrm{~B}_{6,6} \mathrm{C}_{0,51} \mathrm{Cu}_{1,57} \mathrm{Ti}_{1,38}$, obtained under different conditions, by direct point selection, using the demagnetizer part of the hysteresis loops.

2. To calculate the operating points of permanent magnets consisted of $\mathrm{Nd}_{15,2} \mathrm{Fe}_{74,99} \mathrm{~B}_{6,6} \mathrm{C}_{0,51} \mathrm{Cu}_{1,57} \mathrm{Ti}_{1,38}$, obtained under different conditions and by and using the MathCad environment.

3. To calculate the re-magnetization energy for the permanent magnets consisted of $\mathrm{Nd}_{15,2} \mathrm{Fe}_{74,99} \mathrm{~B}_{6,6} \mathrm{C}_{0,51} \mathrm{Cu}_{1,57} \mathrm{Ti}_{1,38}$, obtained under different conditions, by the method of integration along the contour of the maximum hysteresis loop.

4. To calculate the magnetic forces acting in a magnetic damper.

Subject of the study is the material $\mathrm{Nd}_{15,2} \mathrm{Fe}_{75,5} \mathrm{~B}_{6,6} \mathrm{C}_{\mathrm{x}} \mathrm{Cu}_{1,57} \mathrm{Ti}_{1,38}$ and its magnetic characteristics.

Object of the study are magnetic forces acting in a magnetic damper

Methods of the study: modelling.

Expected results. The calculation of operating points makes it possible to use the finished products more efficiently for their intended purpose in the future, and the calculation of re-magnetization energy (energy of losses) will allow to use energy resources more economically.

\section{Presentation of The Basic material AND ANALYSIS OF THE OBTAINED RESULTS}

\subsection{Materials and methods of the study.}

Requirements for magnetic materials:

high coercive power;

low specific gravity;

low cost;

stability of characteristics over a wide temperature and time range;

high electrical resistance.

The use of permanent magnets with high values of coercive force, which characterizes the resistance to demagnetization, the following appears from the peculiarity of this suspension: a magnet in the field of another magnet. The required values of the unloading force can be achieved provided that there is no significant mutual demagnetization of the supporting elements. Cobalt alloys 
and $\mathrm{Nd}-\mathrm{Fe}-(\mathrm{B}, \mathrm{C})$ alloy composites meet this condition. When considering the second type of alloys, the third condition is also fulfilled i.e. low cost compared to cobalt alloys. The specific gravity of the obtained sintered magnets is $9375 \mathrm{~kg} / \mathrm{m}^{3}$.

High electrical resistance of magnetic materials is required to minimize the eddy current losses that occur when the shaft rotates.

In developing the design of the magnetic damper, the then-known magnetic material based on the Sm-Co alloy with known characteristics was used. However, the high cost of Sm, high energy costs for cobalt and the need to preserve the basic characteristics for a long time does not give them a wide enough application. You can use magnets based on alloys of $\mathrm{Fe}-\mathrm{Nd}-\mathrm{B}$ and $\mathrm{Fe}-\mathrm{Nd}-\mathrm{C}$ to reduce the cost of such magnets.

In the table 1 a comparative characteristic of magnets based on the Sm-Co, Fe-Nd-B and Fe-Nd-C systems $\left(T_{K}\right.$ is Curie temperature, $I_{S}$ is spontaneous magnetization, $\mathrm{H}_{\mathrm{A}}$ is anisotropy field, $(\mathrm{BH})_{\max }$ is maximum magnetic energy) is presented. Operating temperatures are about $470 \mathrm{~K}$.

Table 1. Comparative characteristics of magnets based on Sm-Co, Fe-Nd-B and Fe-Nd-C systems $[10,11]$

\begin{tabular}{|c|c|c|c|c|c|}
\hline Composition & $\mathrm{T}_{\mathrm{C}}, \mathrm{K}$ & $\mathrm{I}_{\mathrm{S},} \mathrm{T}$ & $\begin{array}{c}\mathrm{B}_{\mathrm{r}}, \\
\text { Тл }\end{array}$ & $\begin{array}{c}\mathrm{H}_{\mathrm{A}}, \\
\mathrm{MA} / \mathrm{m}\end{array}$ & $\begin{array}{c}(\mathrm{BH})_{\max } \\
\mathrm{kJ} / \mathrm{m}^{3}\end{array}$ \\
\hline $\mathrm{SmCo}_{5}$ & 1020 & 1,14 & 0,77 & 1,3 & 140 \\
\hline $\mathrm{Nd}_{2} \mathrm{Fe}_{14} \mathrm{C}$ & 535 & 1,5 & 0,8 & 7,6 & 450 \\
\hline $\mathrm{Nd}_{2} \mathrm{Fe}_{14} \mathrm{~B}$ & 585 & 1,6 & 1,2 & 5,4 & 512 \\
\hline
\end{tabular}

In this study, permanent magnets of the same composition, which were obtained under different conditions, were investigated (see Table 2).

Table 2. Conditions for obtaining permanent magnets consisted of $\mathrm{Nd}_{15,2} \mathrm{Fe}_{74,99} \mathrm{~B}_{6,6} \mathrm{C}_{0,51} \mathrm{Cu}_{1,57} \mathrm{Ti}_{1,38}$ [25]

\begin{tabular}{|c|c|c|c|}
\hline \multirow{2}{*}{$\begin{array}{c}\text { Examp } \\
\text { le No. }\end{array}$} & $\begin{array}{c}\text { Chemical compo- } \\
\text { sition of perma- } \\
\text { nent magnet }\end{array}$ & $\begin{array}{c}\text { Initial } \\
\text { pressure, } \mathrm{P}, \\
\mathrm{MPa}\end{array}$ & $\begin{array}{c}\text { Sintering / } \\
\text { annealing } \\
\text { temperature, } \\
\mathrm{K}\end{array}$ \\
\hline 1 & \multirow{2}{*}{$\mathrm{Nd}_{15,2} \mathrm{Fe}_{74,99} \mathrm{~B}_{6,6}$} & 0,5 & \multirow{2}{*}{$1323 /$} \\
$\mathrm{C}_{0,51} \mathrm{Cu}_{1,57} \mathrm{Ti}_{1,38}$ & 3 & \\
& & & \\
& & &
\end{tabular}

According to the obtained demagnetizing parts of the hysteresis loop, the operating points were calculated. The values of the intensity $\mathrm{H}$ and the induction $\mathrm{B}$ of the magnetic field, at which the specific magnetic energy of the permanent magnet is maximum. The calculation was performed by direct point selection (see Fig. 1a) and using the MathCad environment (see Fig. 1b). To determine the re-magnetization energy, it is necessary to find the hysteresis loop area by integrating along the loop path.

4.2 Determination of the operating point of a permanent high-energy magnet.

For calculations in MathCad environment [12] the following assumptions were used: if the type of function of dependence $W=f(H, B)$ is known, then, after differentiation of the expression, extremes can be found, which will correspond to the operating points (see Table 3 ). To determine the type of function of the dependence of the magnetic energy $\mathrm{W}$ on the induction $\mathrm{B}$ and the intensity of the magnetic field $\mathrm{H}(W=f(H, B))$, first, it is necessary to determine the dependence of the induction $\mathrm{B}$ on the magnetic field strength $\mathrm{H}(\mathrm{B}=\mathrm{f}(\mathrm{H}))$ in as an $n$ degree polynomial. To solve this problem, splines were constructed in the MathCad environment at the starting points for the samples and a set of $\mathrm{H}-\mathrm{B}$ points was obtained (Fig. 1)

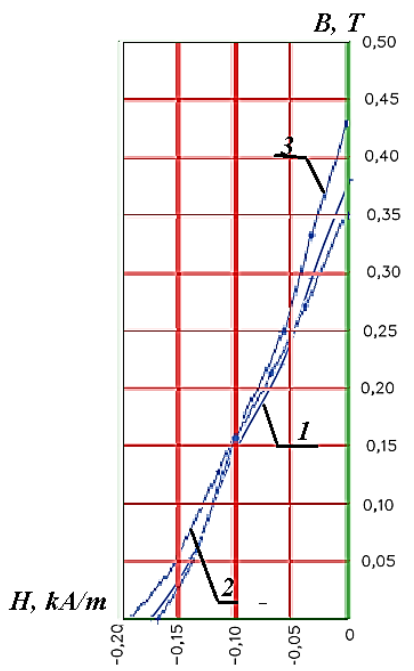

Figure 1. Splines received in MathCad environment

Then, the energy product $W=f(H, B)$ was calculated, the dependence was constructed, and the maximum energy value was determined. The results are shown in Fig. 2 and in Table. 3.

Simultaneously with the obtained set of points H-B in Exel we received polynomials of the third degree. To determine the operating point of a permanent magnet, we must find a derivative of the expression:

$$
W=\frac{B \cdot H}{2}
$$

and solve the equations obtained.

Example No. 1:

$B=1 \cdot 10^{-8} H^{3}+7 \cdot 10^{-6} H^{2}+0,003 H+0,3847$;

$W=0,5 \cdot 10^{-8} H^{4}+3,5 \cdot 10^{-6} H^{3}+1,5 \cdot 10^{-3} H^{2}+0,19235 H$;

$\frac{d W}{d H}=2 \cdot 10^{-8} H^{3}+10,5 \cdot 10^{-6} H^{2}+0,003 H+0,19235$.

Example No. 2:

$B=-6 \cdot 10^{-9} H^{3}-2 \cdot 10^{-7} H^{2}+0,002 H+0,3472$;

$W=-3 \cdot 10^{-9} H^{4}-1 \cdot 10^{-7} H^{3}+0,001 H^{2}+0,1736 H$;

$\frac{d W}{d H}=-12 \cdot 10^{-9} H^{3}-3 \cdot 10^{-7} H^{2}+0,002 H+0,1736$. 
Example No. 3:

$$
\begin{aligned}
& B=2 \cdot 10^{-8} H^{3}+8 \cdot 10^{-6} H^{2}+0,0035 H+0,4353 ; \\
& W=1 \cdot 10^{-8} H^{4}+4 \cdot 10^{-6} H^{3}+1,75 \cdot 10^{-3} H^{2}+ \\
& +0,21765 H ; \\
& \frac{d W}{d H}=4 \cdot 10^{-8} H^{3}+12 \cdot 10^{-6} H^{2}+0,0035 H+0,21765 .
\end{aligned}
$$
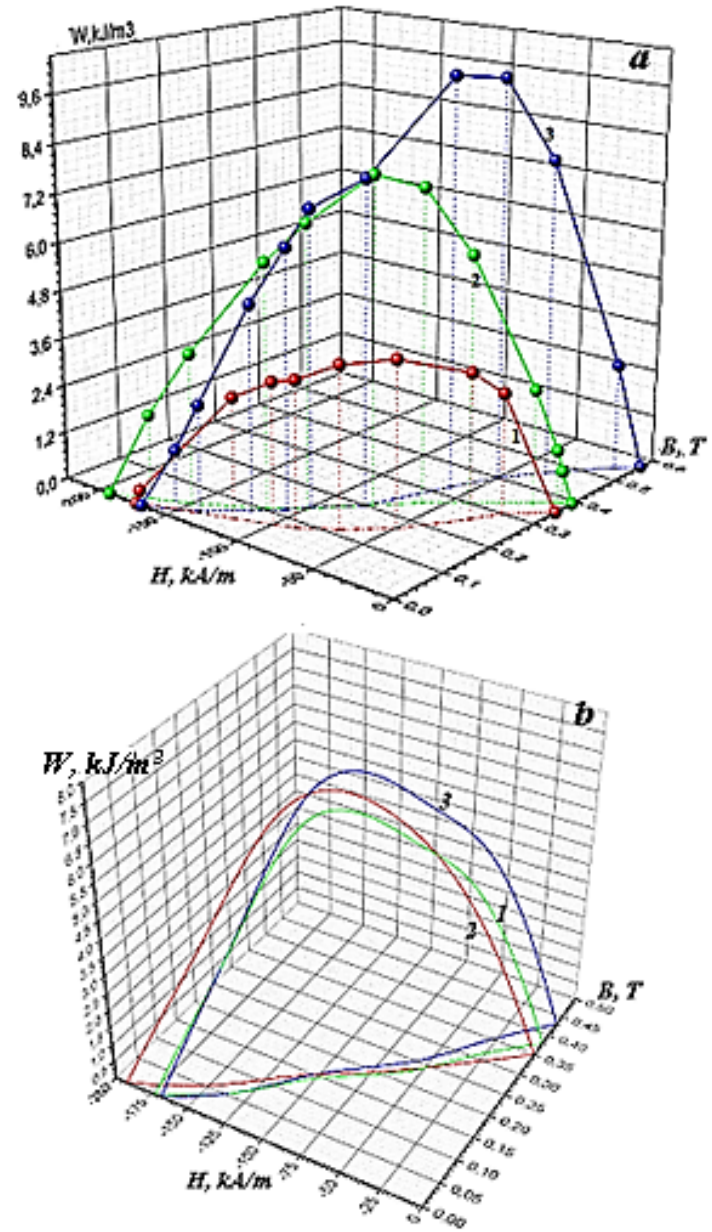

Figure 2. Dependencies $W=f(H, B)$ for examples 1,2 , 3: a) on points, b) in MathCad environment

The results of calculating the operating point for all methods are presented in Table. 3 .

Table 3. The result of calculating the operating points of a permanent magnet for all methods

\begin{tabular}{|c|c|c|c|}
\hline $\begin{array}{c}\text { Example } \\
\text { No. }\end{array}$ & 1 & 2 & 3 \\
\hline $\mathrm{B}, \mathrm{T}$ & 0,17 & 0,21 & 0,33 \\
\hline $\mathrm{H}, \mathrm{kA} / \mathrm{m}$ & $-49,5$ & $-77,5$ & $-61,8$ \\
\hline $\mathrm{W}, \mathrm{kJ} / \mathrm{m}^{3}$ & 4,21 & 8,14 & 10,2 \\
\hline \multicolumn{4}{|c|}{ In MathCad environment } \\
\hline $\mathrm{B}, \mathrm{T}$ & 0,1627 & 0,1622 & 0,184 \\
\hline $\mathrm{H}, \mathrm{kA} / \mathrm{m}$ & $-89,88$ & $-95,17$ & $-87,81$ \\
\hline $\mathrm{W}, \mathrm{kJ} / \mathrm{m}^{3}$ & 7,3094 & 7,7193 & 8,0797 \\
\hline
\end{tabular}

\begin{tabular}{|c|c|c|c|}
\hline \multicolumn{4}{|c|}{ Through the polynomial } \\
\hline $\mathrm{B}, \mathrm{T}$ & 0,136 & 0,140 & 0,181 \\
\hline $\mathrm{H}, \mathrm{kA} / \mathrm{m}$ & $-85,57$ & $-85,60$ & $-77,44$ \\
\hline $\mathrm{W}, \mathrm{kJ} / \mathrm{m}^{3}$ & 5,8176 & 6,0075 & 7,0233 \\
\hline
\end{tabular}

\subsection{Determination of the re-magnetization energy} of a permanent high-energy magnet

The magnetization energy of the examples was calculated as the hysteresis loop area (see Fig. 2).
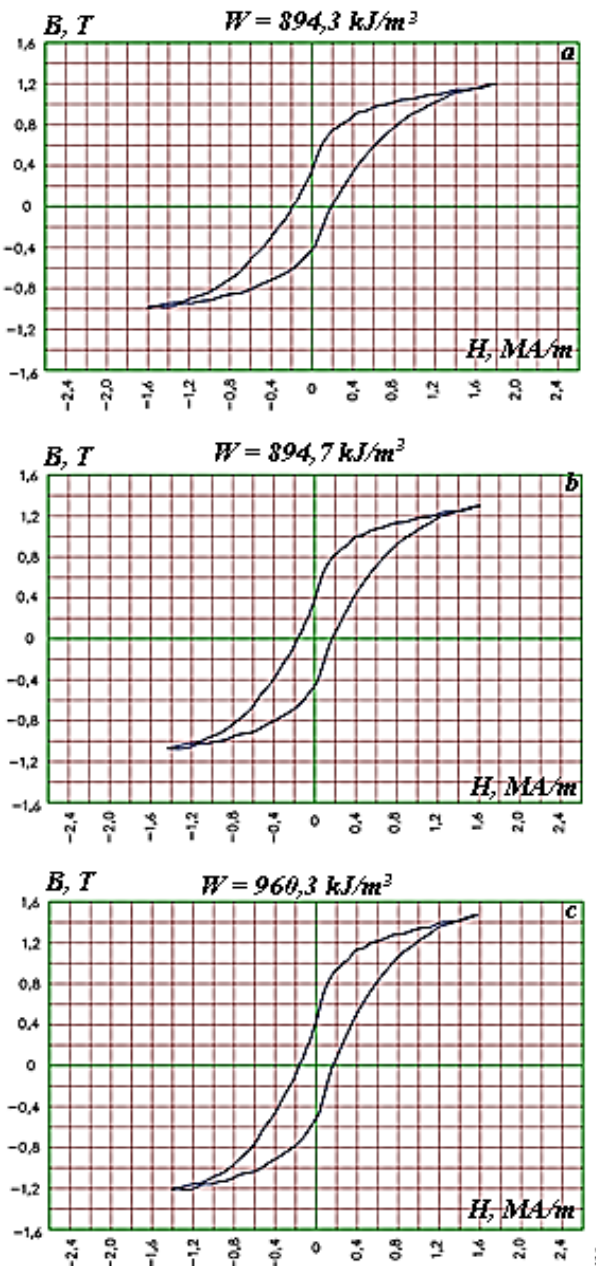

$$
a-0,5 \mathrm{MPa} ; b-3 \mathrm{MPa} ; c-9,5 \mathrm{MPa}
$$

Figure 3. Hysteresis loops for samples consisted of $\mathrm{Nd}_{15,2} \mathrm{Fe}_{74,99} \mathrm{~B}_{6,6} \mathrm{C}_{0,51} \mathrm{Cu}_{1,57} \mathrm{Ti}_{1,38}$ caused under different conditions

To accomplish this task, splines were obtained and the area of the figures was calculated by numerical methods. Given that the samples under study were in the shape of a cylinder $\mathrm{h}=5 \mathrm{~mm}$ and $\mathrm{d}=9 \mathrm{~mm}\left(\mathrm{~S}=3,18 \cdot 10^{-}\right.$ ${ }^{7} \mathrm{M}^{2}$ ), it is possible to find the real re-magnetization energy for each sample. The results of the calculations are presented in Table. 4. 
Table 4. The value of the specific and real energy of the re-magnetization of the samples

\begin{tabular}{|c|c|c|c|}
\hline Example No. & 1 & 2 & 3 \\
\hline \multicolumn{4}{|c|}{ Numerical Methods } \\
\hline $\mathrm{W}_{\text {пит }}, \mathrm{kJ} / \mathrm{m}^{3}$ & 894,3 & 894,7 & 960,3 \\
\hline $\mathrm{W}, \mathrm{J}$ & 0,2844 & 0,2845 & 0,3054 \\
\hline \multicolumn{4}{|c|}{ By points } \\
\hline $\mathrm{W}_{\text {пит }}, \mathrm{kJ} / \mathrm{m}^{3}$ & 784,5 & 792,6 & 869,7 \\
\hline $\mathrm{W}, \mathrm{J}$ & 0,2495 & 0,2521 & 0,2766 \\
\hline
\end{tabular}

\section{damper}

\subsection{Calculation of magnetic forces in a magnetic}

Magnetic damper is a device that provides protection of precision apparatus, equipment against external forces such as vibration, shock, rotational oscillations due to energy imbalance, etc. The magnetic damper belongs to the field of electrical engineering and can be used to dampen vibrations and kinetic energies. Fig. 3 shows the design of the rotor and stator rings.

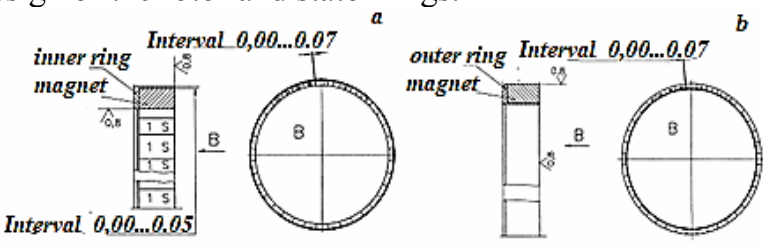

Figure 4. Design of rotor and stator rings

The developed magnetic damper consists of rotating part i.e. rotary and fixed part (stator). The rotary part of the magnetic damper consists of a set of radially magnetized sectors, assembled in a ring of non-magnetic steel (EP 33-W) and mounted in a clamp of magnetic steel (EP $609-W)$ with alternating magnetic poles of each pair of segment rings. The fixed part of the damper is assembled from segments of radially magnetized permanent magnets assembled in a ring of non-magnetic steel (EP 33-W) and mounted in a clamp of magnetic steel (EP $609-$ W) with alternating magnetic poles of each pair of segment rings. Thus, the rotor and stator magnet poles create a repulsive force around the circle. Fig. 4 presents a sleeve with magnets.

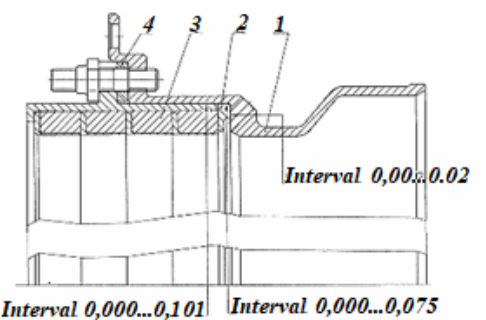

Figure 5. Magnet sleeve: 1 - sleeve, 2 - ring, 3 - magnet sleeve, 4 - adjusting ring

Earlier, according to the results of studies of Permanent Magnetic Damper Bearings the following conclusion was made: as the radius of the support increases, its load capacity increases linearly and the weight of the shaft increases squared. That is, under certain conditions, the support will only compensate for the weight of the shaft. Therefore, the shaft must be empty and the inner bearing rings are minimal [2].

The following formula was used to calculate the unloading force:

$$
F=\frac{\mu_{0} \cdot J^{2} \cdot l \cdot(r+x / 2)}{2} \cdot e^{-\frac{\pi \cdot x}{d}} \cdot \sin \varphi
$$

Magnetic saturation can be defined as follows:

$$
J=\frac{B}{\mu_{0}}-H
$$

Totally, 390 magnets are used in this design. The size of the magnets used in the construction is $6 \times 12 \times 16$ $\mathrm{mm}$, height is $6 \mathrm{~mm}$, the working part of the magnet is $12 \times 16 \mathrm{~mm}$, so this plane can be divided into 12 elementary magnets square section. Thus, per one magnet, the value of the unloading force, obtained by the formula No. 7 , must be increased by 12 times.

Using the data in Table. 3, we determine the unloading force according to the formula (1). To calculate the dependence of this force on the magnitude of the gap in the magnetic damper, it was considered that the sine of the angle of rotation is maximum [2].

It is known that the smaller the gap in the damper, the greater the unloading force can be achieved [4, 7-9]. It should be noted that the manufacturing features do not allow to reduce the gap to the minimum values. In the proposed design, the gap is $1 \mathrm{~mm}$. Figure 5 presents the dependence of the unloading force on the gap in the magnetic damper. Figure $5 \mathrm{~b}$ presents the dependence of the unloading (axial) force on the values of the intensity and induction of an external magnetic field for sintered magnets consisted of Nd-Fe-B doped with $\mathrm{Cu}, \mathrm{C}$, Ti in a magnetic damper.
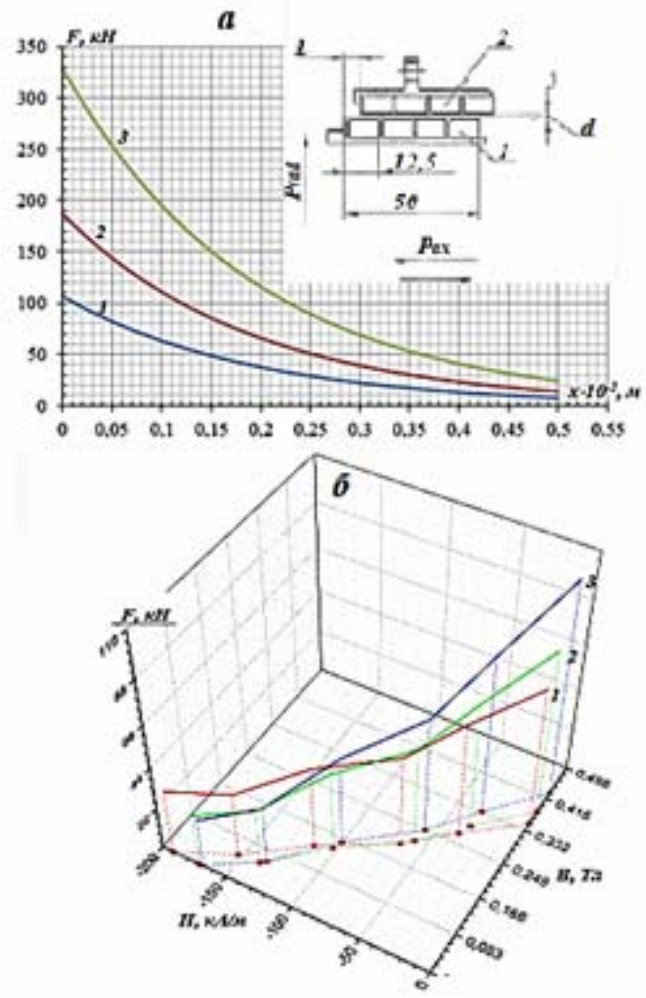

Figure 6. The dependence of the unloading (axial) force on the gap (a) and on the values of the intensity and induction of the external magnetic field (b) in the magnetic damper for examples No. 1, 2, 3 


\section{CONCLUSION}

1. The analysis of the obtained results showed that the values of the operating points of the permanent magnet, which are determined by direct selection of points and when using the MathCad environment, almost do not differ. This indicates the validity of the simulation results obtained in MathCad environment.

2. The calculation of the demagnetization energy showed that these values depend significantly on the method of obtaining a permanent magnet.

3. The design of the magnetic shaft of the fan shaft with a magnetic damper, which is engaged to test the possibility of using this type of damper additional support for long shafts of aircraft engines. This design of the support does not require the traditional supply of lubricant for cooling the bearing and is devoid of the typical disadvantages of shaft supports.

4. The dependence of the unloading (axial) force on the gap in the magnetic damper is presented. We can see that as the gap increases, the value of the unloading force decreases.

5. The dependence of the unloading (axial) force on the values of the intensity and induction of an external magnetic field for sintered magnets of $\mathrm{Nd}-\mathrm{Fe}-\mathrm{B}$ composition doped with $\mathrm{Cu}, \mathrm{C}$, $\mathrm{Ti}$ in a magnetic damper is presented. We can see that when the magnetic field is close to " 0 ", the value of the unloading force decreases.

\section{REFERENCE}

[1] Martynenko, G.Y. (2007) Determination of the stiffness characteristics of the radial magnetic bearings in two circular permanent magnet [Opredelenie zhestkostnykh kharakteristik radialnykh magnitnykh podshipnikov na dvukh koltsevykh postoiannykh magnitakh]. Visnyk NTU «HPI». Tem. vyp. «Dynamika $i$ micnist' mashyn» - Bulletin of NTU "KHPI". The vol. "Dynamics and strength of machines", 38, 83-95. [in Russian]

[2] Metlin, V.B. (1968) Magnetic and magnetohydrodynamic support [Magnitnye i magnitogidpodinamicheskie opory]. Moscow: Energy. [in Russian]

[3] Design-schematic solution (Konstruktivno-shemnoe reshenie) [Electronic resource] .- URL access mode: http://www.aviagazoturbina.ru/index.php/konstruktiv no-shemnoe-reshenie. [in Russian]

[4] Bolotov A. N. \& Fucking V. L. (2008) Tribology magnetoactive bearings: monograph. Tver: TSTU. [in Russian]

[5] Patent No. RU2287729C1. Electromagnetic damper [Electronic resource] / E. V. Sidorov, G. S. Tyukavin. - Mode of access URL: http://www.findpatent.ru/patent /228/2287729.html. [in Russian]

[6] Gulyaeva T. V. Gulyaeva L. V., Tatarchuk O. V. (2018) Magnetic damper for aircraft engined-436T. Science and Education a New Dimension: Natural and Technical Sciences, VI (18), Is: 158, P. 51-55: https://doi.org/10.31174/NT2018-158VI18-13 (in English)

[7] Zhuravlev Yu. N. (2003) Active magnetic bearings: Theory, calculation, application. (Aktivnyie magnitnyie podshipniki: Teoriya, raschet, primenenie) $\mathrm{SPb}$ : Polytechnic. [in Russian]

[8] Petzold O. (2006) Hybridmagnete für einen magnetisch gelagerten Rundtisch. Technische mechanik, Band 26, Heft 2, P. 85-86. (in English)

[9] Neumann L.R., Demyrchan K. S. (1981) Theoretical foundations of electrical engineering (Teoreticheskie osnovyi elektrotehniki), 250 p. [in Russian]

[10]Krynchyk H.S. (1976) Physics of magnetic phenomena (Fizika magnitnyih yavleniy), 262 p. (Russian)

[11]Vonsovskyi S.V. (1971) Magnetism (Magnetizm), 1032 p. [in Russian]

[12]Makarov E.H. (2005) Engineering calculations in MathCad. Training course (Inzhenernyie raschetyi $v$ MathCad. Uchebnyiy kurs), 448 p. [in Russian]

[13]Brekharya G. P., Kharitonova E. A., Gulyaeva T. V. (2014) Properties of the permanent magnets $\mathrm{Nd}-\mathrm{Fe}-$ $B$ alloy with $\mathrm{Cu}, \mathrm{Ti}, \mathrm{C}$, obtained by a powder method or sintering of the films at high pressure. Progress in physics of metals. IMF, 15, 35-53. [in Russian]

[14]Gulyaeva T. V., Kolomoets A. E., Gulyaev V. S., Behara N. V. (2007) Obtaining magnetic materials needed for the magnetic dampers of aircraft engines, Bulletin of the engine. Zaporozhye JSC "Motor Sich", № 2, 189 - 193. [in Russian]

[15]Gulyaeva T. V. (2015) Proposed rational leguana Reimu Spinna econome-legovini Shvidko hologenic splavu $\mathrm{Nd}-\mathrm{Fe}-\mathrm{B}-\mathrm{Ti}-\mathrm{C}-\mathrm{Cu}$ for paviment magnetic feature: dis. on zdobuttya Sciences. Stupina candidate. tech. SC.: spec. 05.16.01 "Metaloplast Termona obrobka metalu" / T. V. Gulyaeva - Zaporizhzhya, $175 \mathrm{p}$ [in Ukrainian]

[16] Read more about gas turbine engines of the family of $D-436$. State enterprise "Zaporozhye machinebuilding design Bureau "Progress" named after academician A. G. Ivchenko [Electronic resource]. Mode of access URL: http://www.zmkb.com/welcome.do?id=146 guidance for those operating. [in Russian]

The article was received 01.03.2020

\section{РОЗРАХУНОК МАГНІТНОГО ДЕМПФЕРУ}

ТАТАРЧУК Т.В. канд. техн. наук, доцент кафедри фізики Національного університету «Запорізька політехніка», Запоріжжя, Україна, е-mail: tanko.ho1@gmail.com; 
ГАВРОВ A.I.

студент гр. E-127cn Національного університету «Запорізька політехніка», Запоріжжя, Україна, е-таil: lordbusya@gmail.com;

МАСЛОВ С.О. студент гр. E-127cn Національного університету «Запорізька політехніка», Запоріжжя, Україна, е-mail: ser.maslov.97@gmail.com.

Мета роботи. Дослідити залежність магнітних властивостей матеріалу від його хімічного складу, щуо отриманий за різного тиску при певних температурах. На основі певного складу та властивостей цього матеріалу дослідити, як змінюються його робочі точки та втрати на перемагнічення, щяо в свою чергу впливатиме на конструкцйні та експлуатаційні особливості магнітного демпферу двигуна.

Методи дослідження. Вибір екстремумів функиї залежності енергії магніту від індукиії та напруженості через диференціювання виразу, розрахунок робочих точок магніту методом підбіру та за допомогою середовища MathCad, визначення енергії перемагнічення через інтегрування петлі гістерезису, аналітичний розрахунок магнітних сил у магнітному демпфері, використовуючи формули з дослідів демпферних опор Бекерса.

Отримані результати. У ході виконання поставленого завдання було визначено робочі точки петлі гістерезису магніту, у яких магнітна енергія найбільша шляхом диференціювання виразу залежності енергї магніта від індукиії та напруженості. На основі ичих данних було виявлено максимальну магнітну індукцію такоеричитивну силу магнітного поля у циих точках. Ці точки характеризують найбільшу питому енергію магніта, яку надалі використовують за призначенням. Далі, спираючись на петлю гістерезиса, иляхом інтегрування було знайдено енергію втрат на перемагнічення магніту. За иими даними було розраховано розвантажуючу силу магнітного демпфера.

Наукова новизна. Було проведено більш точний аналіз магнітних процесів у магнітних матеріалах за допомогою математичного апарату, з використанням програмних середовищ, такі як MathCad, OriginLaB. Проаналізована залежність магнітних властивостей матеріалу від його хімічного складу, енергї̈ та втрат, щзо в свою чергу робить більш ефективним використання постійного магніту у техніці, апаратах та машинах.

Практична цінність. За отриманими результатами розрахунку енергї втрат та робочих точок магніту визначається оптимальний хімічний склад, його геометричний розмір, щзо дозволяє знизити втрати на виробництво, зекономити матеріали при ичьому підвищити корисну дію магнітного матеріалу у конструкиї двигунів. При цььому збільшується експлуатаційний строк роботи машин, їх надійність. Оптимальні розміри магнітів в обмотках забезпечують потрібні повітряні проміжки, щзо в свою чергу через відсутність тертя зменшують втрати, щьо збільиуює розвантажуваючу силу.

Ключові слова: магнітні матеріали; петля гістерезису; робоча точка; енергія втрат; магнітний демпфер; магнітна індукція, розвантажувальна сила, індукція насичення, напруженість, коерцитивна сила.

\section{РАСЧЕТ МАГНИТНОГО ДЕМПФЕРА}

ТАТАРЧУК Т.В. канд. техн. наук, дочент кафедры физики Национального университета «Запорожская политехника», Запорожье, Украина, e-mail: tanko.ho1@gmail.com;

ГАВРОВ А.И. студент гр. E-127cn Национального университета «Запорожская политехника», Запорожье, Украина, е-таil: lordbusya@gmail.com;

МАСЛОВ С.А. студент гр. E-127cn Наџионального университета «Запорожская политехника», Запорожье, Украина, е-mail: ser.maslov.97@gmail.com.

Цель работы. Исследовать зависимость магнитных свойств материала от его химического состава, полученный за разного давления при определенных температурах. На основе определенного состава и свойств этого материала исследовать, как меняются его рабочие точки и потери на перемагничивания, что в свою очередь повлияет на конструкцйни и эксплуатационные особенности магнитного демпфера двигателя.

Методы исследования. Выбор экстремумов функции зависимости энергии магнита от индукции и напряженности из-за дифференцировки выражения, расчет рабочих точек магнита методом подбор и с помощцью среды MathCad, определения энергии перемагничивания через интегрирование петли гистерезиса, аналитический расчет магнитных сил в магнитном демпфере, используя формульы из опытов демпферных опор Бекерса.

Полученные результаты. В ходе выполнения поставленной задачи были определены рабочие точки петли гистерезиса магнита, в которых магнитная энергия самая путем дифференцирования выражения зависимости энергии магнита от индукции и напряженности. На основе этих данных было обнаружено максимальную магнитную индукцию такоерцитивну силу магнитного поля в этих точках. Эти точки характеризует наибольшую удельную энергию магнита, которую в дальнейшем используют по назначению. Далее, опираясь на 
петлю гистерезиса, путем интегрирования был найден энергию потерь на перемагничивания магнита. По этим данным было рассчитано разгружая силу магнитного демпфера.

Научная новизна. Было проведено более точный анализ магнитных процессов в магнитных материалах $c$ помощью математического аппарата, с использованием программных сред, такие как MathCad, OriginLaB. Проанализирована зависимость магнитных свойств материала от его химического состава, энергии и потерь, в свою очередь делает более эффективным использование постоянного магнита в технике, аппаратах и машинах.

Практическая ценность. По полученным результатам расчета энергии потерь и рабочих точек магнита определяется оптимальньй химический состав, его геометрический размер, что позволяет снизить потери на производство, сэкономить материаль при этом повысить полезное действие магнитного материала 6 конструкиии двигателей. При этом увеличивается эксплуатационный срок работы машин, их надежность. Оптимальные размеры магнитов в обмотках обеспечивают нужны воздушные промежутки, в свою очередь из-за отсутствия трения уменьшают потери, збильшуюе розвантажуваючу силу.

Ключевые слова: магнитные материалы; петля гистерезиса; рабочая точка; энергия потерь; магнитный демпфер; магнитная индукция, разгрузочная сила, индукция насыщения, напряженность, коэрцитивная сила. 